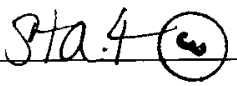

APR 251997 ENGINEERING DATA TRANSMITTAL

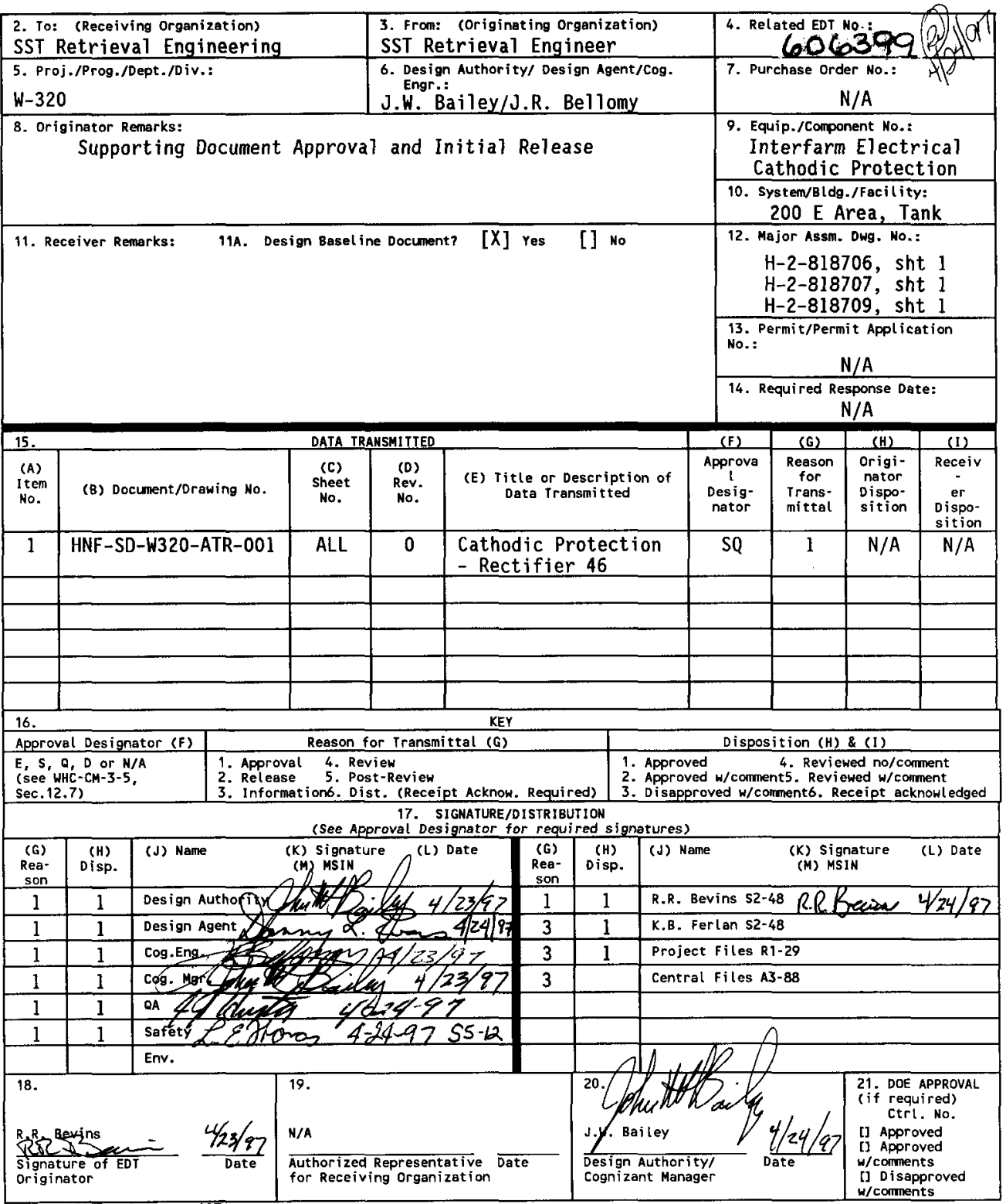




\title{
Cathodic Protection-Rectifier 46
}

\author{
J. R. Bell lomy
}

SGN Eurisys Services Corporation (SESC), Richland, WA 99352

U.S. Department of Energy Contract DE-AC06-96RL13200

EDT/ECN: 610596

Org Code: $\$ 1100$

B\&R Code: EW3130010
UC: 510

Charge Code: D2M2N

Total Pages: $3837 \mathrm{kmh}$

Key Words: Project W-320, Interfarm Cathodic Protection, Rectifier 46

Abstract: Acceptance Test Report for the interfarm cathodic protection -Addition of rectifier 46, Project $W-320$

TRADEMARK DISCLAIMER. Reference herein to any specific commercial procuct, process, or service by trade nane, tradenark, manufacturer, or otherwise, does not necessarily constitute or inply its endorsentent, recommendation, or favoring by the United States Government or any agency thereof or its contractors or subcontractors.

Printed in the United States of America. Io obtain copies of this document, contact: Document Control Services, P.O. Box 950, Mailstop H6-08, Richland WA 99352, Phone (509) 372-2420;

Fax (509) 376-4989.
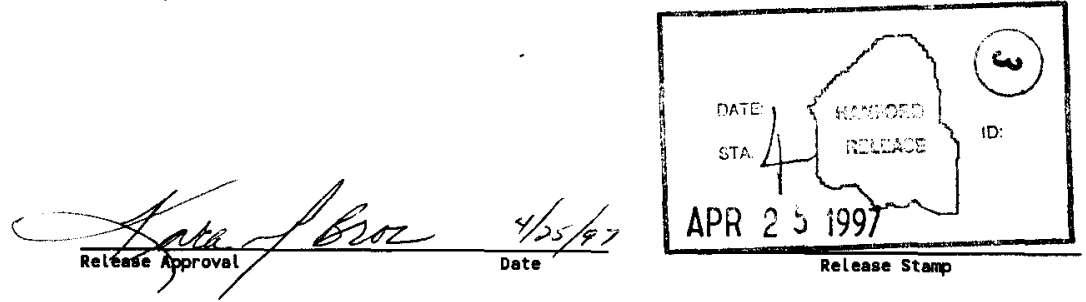

\section{Approved for Public Release}


TEST TITLE Cathodic Protection - Rectifier 46

LOCATION 200-E Area (Near corner of 7 th Avenue and Buffalo Avenue)

PROJECT NUMBER $W-320$ WORK ORDER ER4319

PROJECT TITLE Tank 241-C-106 Sluicing

\author{
Prepared By \\ ICF Kaiser Hanford Company \\ Richland, Washington
}

For the U.S. Department of Energy

Contract DE-AC06-93RL.12359

PROCEDURE APPROVAL

ICF KAISER HANFORD COMPANY (ICF KH)

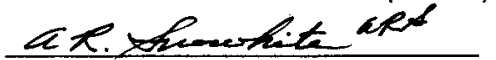

Originator

CQublete

meto

$7-14-95$
$70-10-94$ Date 4.14 .95

Checker foresubitr 10-19.94

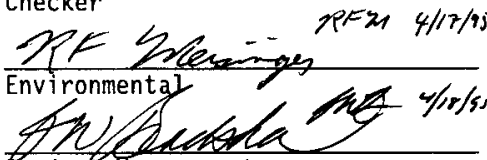

Project Management

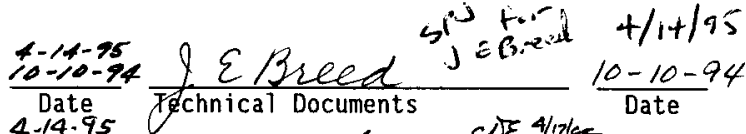

cos 4/17/se

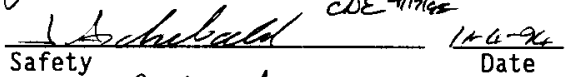

Westinghouse Hanford Company (WHC)

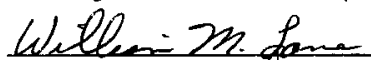

Projects Department

saffety
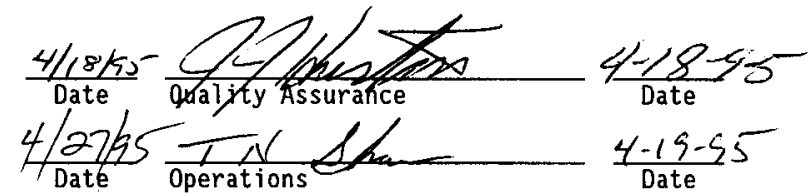

$\frac{4-19-55}{\text { Date }}$ 
EXECUTION AND TEST APPROVAL wetleam theceven

FOR BOETTCHER
ED. BOET

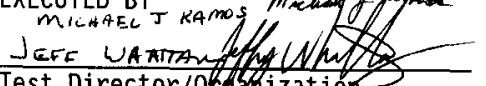

Test Director/orgtorization

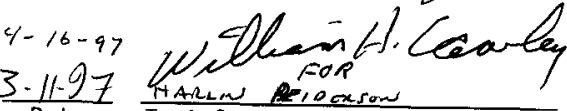

$4-16-92$

Sland angle / FONA

Foore sumber

Recorder/Organization

E. Enzois Fow

WITNESSES

$\frac{N A}{\text { Witness/Organizatiol }}$

Date

Test Operator/Organization

$\frac{3-10-97}{\text { Date }}$

$\frac{3 / 10 / 4 z}{\text { Date }}$

$4-15-97$

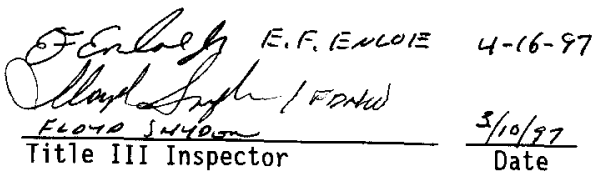

$\frac{\Lambda A}{\text { Witness/Organization }}$

$\sim A$

Date Witness/Organization

A-E APPROVAL

ICF Kaiser Hanford Company (ICF KH)

Without

exceptions

With exceptions

Sand-f Lemen

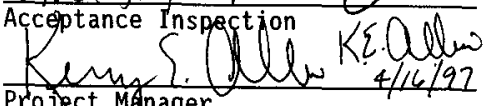

Project Mänager resejved

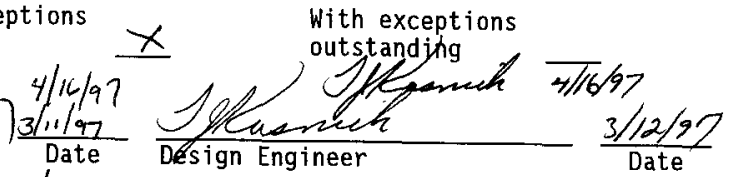

$3 / 13 / 97$

Date

TEST APPROVAL AND ACCEPTANCE

Westinghouse Hanford Company (WHC)

Without

exceptions

With exceptions
resolved

With exceptions

outstanding

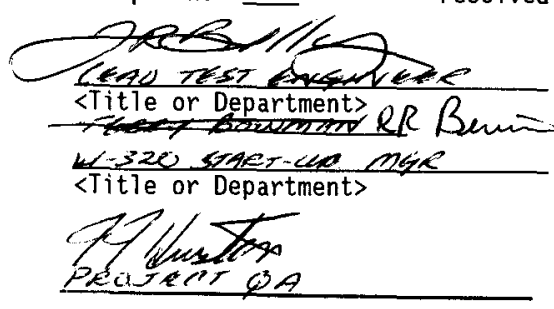

Alokg

Mau w. Ientá

(4) 72 (2)

$4=320$ steE

<Title or Department>

$\frac{W / 14 / 97}{\text { Date }}$

luszo peatent mhe

<Title or Department>

2 granem

Cathofic Protection Engineer

TERRY $T$ BOWMAN

$\frac{4-18-97}{D+15}$

W320001.ATP. 614 
Section

TITLE/PROCEDURE APPROVAL

EXECUTION AND TEST APPROVAL

TABLE OF CONTENTS

1 PURPOSE

REFERENCES

3 RESPONSIBILITIES 4

4 CHANGE CONTROL 7

5 EXECUTION 7

6 EXCEPTIONS 7

7 PREREQUISITES, EQUIPMENT/INSTRUMENTS, AND ABBREVIATIONS 8

8 RECTIFIER, CABLES, PIPE TEST CONDUCTORS, NATIVE POTENTIALS, ANODES, AND SYSTEM OPERATION

EXCEPTION FORM

EXCEPTIONS

NOTE: At completion of test, enter pages added during performance of test to this Table of Contents. 
$1 \quad$ PURPOSE

This Acceptance Test Procedure (ATP) has been prepared to demonstrate that the cathodic protection system functions as required by project criteria.

2 REFERENCES

2.1 DRAWINGS

H-2-818706, Sh 1, Rev 0 Electrical - Cathodic Protection Plan \#1

H-2-818707, Sh 1, Rev 0 Electrical - Cathodic Protection Plan \#2

H-2-818709, Sh 1, Rev 0 Electrical - Cathodic Protection Details

2.2 SPECIFICATIONS

W-320-C1, Rev 0 Construction Specification (Section 16640)

2.3 ENGINEERING CHANGE NOTICES (ECN)

Prior to final test approval, enter ECNs written against this ATP.

3 RESPONSIBILITIES

3.1 GENERAL

Each company or organization participating in this ATP will designate personnel to assume the responsibilities and duties as defined herein for their respective roles. The designees shall become familiar with this ATP and the systems involved to the extent that they can perform their assigned duties.

3.2 WHC PROJECT ENGINEER

3.2.1 Designates a Test Director.

3.2.2 Coordinates testing with the Facility Manager.

3.2.3 Acts as liaison between the participants in acceptance testing.

3.2.4 Distributes the approved testing schedule before start of testing.

3.2.5 Schedules and conducts a pretest kickoff meeting with test participants when necessary.

3.2.6 Notifies the persons performing and witnessing the test 2 days before the start of testing.

3.2.7 Schedules a dry run when necessary.

3.2.8 Notifies concerned parties when a change is made in the testing schedule. 
3.2.9 Signs Execution and Test Approval page when test is approved and accepted.

3.2.10 Takes necessary action to clear exceptions to the test.

3.2.11 Signs Exception Form when exception has been resolved.

3.2.12 Provides a distribution list for the approved and accepted ATP(ATR).

\subsection{TEST DIRECTOR}

3.3.1 Coordinates and directs acceptance testing.

3.3.2 Confirms that field testing and inspection of the system or portion of the system to be tested has been completed.

3.3.3 Stops any test which, in his or her judgment, may cause damage to the system until the problem has been resolved.

3.3.4 After verifying there is no adverse impact, may alter the sequence in which systems or subsystems are tested.

3.3.5 Ensures that required environmental conditions are maintained.

3.3.6 If a test is to be suspended for a period of time, ensures that the system is left in a safe mode.

3.3.7 Before restarting suspended test, reverifies the test prerequisites.

3.3.8 Initiates ECNs to document required changes to the ATP.

3.3.9 Reviews recorded data, discrepancies, and exceptions.

3.3.10 Obtains information or changes necessary to clear or resolve objections during the performance of the test.

3.3.11 Signs Execution and Test Approval page when test has been performed.

3.3.12 Signs Exception Form when exception has been resolved.

3.3.13 Obtains required signatures on the ATP Master prior to reproduction and distribution.

3.4 WITNESSES (Provided by Participating Organizations. One witness shall be a Title III acceptance inspector.)

3.4.1 Witness the tests.

3.4.2 Review results of testing.

3.4.3 Assist the Test Director when requested.

3.4.4 Sign Execution and Test Approval page when test has been performed.

3.4.5 Sign Exception Form when exception has been resolved. 
3.5 RECORDER (Provided by ICF KH)

3.5.1 Prepares a Field copy from the ATP Master.

3.5.2 Records names of all designated personnel on Field copy of ATP prior to start of testing.

3.5.3 Records test instrument identification numbers and calibration expiration dates.

3.5.4 Initials and dates every test step on the Field copy as it is completed next to the step number or on a data sheet, when provided. Records test data. On data sheets where there is not room for both the initial and date, date may be entered at bottom of column.

3.5.5 Records objections and exceptions on an Exception form. Uses additional Exception forms as needed. Notifies the Test Director at time the objection is made.

3.5.6 Signs Execution and Test Approval page when test has been performed.

3.5.7 After test is finished, assigns alpha numeric page numbers to added data sheets and Exception forms. Records page numbers in the Table of Contents.

3.5.8 Transfers Field copy entries for each step to the Master in ink or type, signs, and dates. Transmits the completed Master to the Test Director for approval signature routing. Transmits the Field copy to Construction Document Control for inclusion in the official project file.

3.5.9 Signs Exception Form when exception has been resolved and transmits to Test Director.

\subsection{TEST OPERATOR}

3.6.1 Performs test under direction of the Test Director.

3.6.2 Provides labor, equipment, and test instruments required for performing tests which have not been designated as being provided by others.

3.6.3 Requests in writing from the Test Director those services, materials, or equipment that have been designated as being supplied by others.

3.6.4 Confirms that all equipment required for performing test will be available at the start of testing.

3.6.5 Signs the Execution and Test Approval page.

\subsection{DESIGN ENGINEER ACCEPTANCE INSPECTION}

3.7.1 Evaluate results.

3.7.2 Sign for A-E Approval on Execution and Test Approval page.

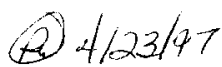

W320001.ATP.614 
Required changes to this ATP must be processed on ECNs in accordance with company procedures. If a need for change is discovered in the course of running the test, the test shall be stopped until the ECN is approved. However, this does not prevent the running of another portion of the test unaffected by the change.

\subsection{OCCUPATIONAL SAFETY AND HEALTH}

Individuals shall carry out their assigned work in a safe manner to protect themselves and others from undue hazards and to prevent damage to property and environment. Facility line managers shall assure the safety of activities within their areas to prevent injury, property damage, or interruption of operation. Performance of test activities shall always include safety and health aspects.

\subsection{PERFORMANCE}

5.2.1 Conduct testing in accordance with ICF KH Procedure CON 3.5 (Performance and Recording of Acceptance Test Procedures).

5.2.2 Perform test following the steps and requirements of this procedure.

6 EXCEPTIONS

6.1 GENERAL

Exceptions to the required test results are sequentially numbered and recorded on individual Exception forms. This enables case-by-case resolution and approval of each exception.

Errors/exceptions in the ATP itself shall NOT be processed as test exceptions (see Section 4 CHANGE CONTROL).

\subsection{RECORDING} 6.2.1 Number each exception sequentially as it occurs and record it on an
Exception Form (KEH-428), sample appended.

6.2.2 Enter name and organization of objecting party for each exception.

6.2.3 Enter planned action to resolve each exception when such determination is made.

\subsection{RETEST/RESOLUTION}

Record the action taken to resolve each exception. Action taken may not be the same as planned action.

6.3.1 When action taken results in an acceptable retest, sign and date Retest Execution and Acceptance section of the Exception Form. 
6.3.2 When action taken does not involve an acceptable retest, strike out the Retest Execution and Acceptance section of the Exception Form.

6.4 APPROVAL AND ACCEPTANCE

WHC provides final approval and acceptance of exceptions by checking one of the following on Exception Form:

6.4.1 Retest Approved and Accepted: Applicable when Retest Execution and Acceptance section is completed.

6.4.2 Exception Accepted-As-Is: Requires detailed explanation.

6.4.3 Other: Requires detailed explanation.

WHC signs and dates the Exception Form and obtains other WHC internal approvals, if required.

\subsection{DISTRIBUTION}

A copy of the approved Exception Form is distributed to each participant. The signed original is attached to the ATP Master.

7 PREREQUISITES, EQUIPMENT/INSTRUMENTS, AND ABBREVIATIONS

7.1 PREREQUISITES

The following conditions shall exist at start of testing for that portion of the system being tested.

7.1.1 Buried interfarm piping and the cathodic protection system have been inspected for compliance with construction documents.

7.1.2 Reference documents (including this ATP) have been verified for correct revision number and outstanding ECNs.

7.1.3 A Prejob Safety Analysis has been prepared and a Prejob Safety Meeting has been conducted.

7.1.4 Test instruments (except Waveform Analyzer) have a valid calibration stamp attached. Test instrument identification numbers and calibration expiration dates have been recorded in Para 7.2.

\subsection{EQUIPMENT/INSTRUMENTS}

Supplied by Test Operator unless otherwise noted. (Delete items not required. Add any additional necessary items.

7.2.1 Voltohmmeter (VOM): Digital, portable, $0-150 \mathrm{~V} \mathrm{ac} / \mathrm{dc}$.

Instrument No. $812-45-08-011$ $954-4^{5}-68-005$

7.2.2 Waveform Analyzer: Hand held instrument with display of ON-OFF pipeto-soil potential, DC potential or $A C$ potential, MCMiller $\mathrm{Co}$, Model WFA-1. 
7.2.3 Test leads with insulated covers for wire clips.

7.2.4 Portable test reel, containing a minimum of 200 feet of test wire, $600 \mathrm{~V}$, No. 18 AWG minimum.

7.2.5 Portable copper-copper sulphate reference electrode.

7.2.6 Pipe locator.

7.3 ABBREVIATIONS

ECN Engineering Change Notice 
8.1 The following steps will verify (1) rectifier nameplate data, (2) rectifier input wiring is correctly terminated and color coded, and (3) anode header cable, anode loop cable, and negative return cables are labeled and connected in accordance with the design.

9/16/968.1.1 Record nameplate data for Rectifier 46 .

Make
Model
Serial Number
AC Line Input Voltage
AC Line Frequency
Number of Phases
DC Output Voltage
DC Output Current

GOOD $-4 \angle L 12 \angle R C \times R 1 C$

CSOYSA 24-12 GLMPT2

9503223

$\frac{\frac{120}{879896} 60}{\frac{24}{12}}$

\section{E 91996}

8.1 .2

Eट g/18196

8.1.2.1

स6 $910 \%$

Q6 918196

dद $9 / 19 / 96$

excenor 1

07 918186

8.1.2.2

8.1.2.3

8.1.3

8.1.4

8.1.5

8.1 .6

$4 / 198$

8.1.6.1

8.1.6.2

8.1 .6 .3

8.1.7

$9 / 18 / 96$

8.1.7.1

8.1 .7 .2

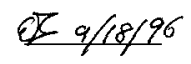

Verify the following on rectifier:

Tank gasket is not damaged and is in place.

There are no loose electrical connections or frayed wires.

There are no oil leaks.

Verify disconnect switch at rectifier is OPEN.

Using a VOM, verify no de voltage at rectifier output terminals.

Verify rectifier case is filled with oil to the indicated level and that oil is CLEAR.

Verify ac supply wiring from disconnect switch is terminated on ac input terminals of rectifier.

W320001.ATP. 614

$-10-$

(E) $4 / 2367$ HNFWHE-SD-W320-ATR-001

Rev 0 

8.1 .7 .3
(-) R46
(Negative return cable)

8.1 .8

Verify Anode Header Cable and Anode Loop Cable are terminated at rectifier positive terminals.

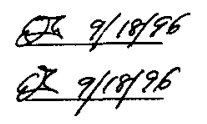

8.1.8.1 (t) HR46 (Anode Header Cable)

8.1 .8 .2

(+) LR46

(Anode Loop Cable)

8.1 .9

Verify Negative Return Cable is terminated at rectifier negative terminal.
Q7) 910796
8.1.9.1
or $9 / 18 / 96$
$8.1 \cdot 10$
8.1 .11

(-) R46
Verify rectifier frame is connected to ground rod.
Verify Anode Header Cable (+) HR46 and Anode Loop Cable (+) LR46 are connected together at Anode Junction Box AJB $(46-1)$ and $A J B(46-2)$.

\section{2}

The following steps will verify continuity of the Anode Reader Cable and the Anode Loop Cable.

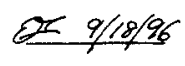

8.2 .1

Record the following VOM data:

Manufacturer
Mode 1

Serial Number

Calibration Sticker Data

$\frac{\frac{8060 A}{812-45-08-061}}{\frac{9-25-96}{}}$

Disconnect Anode Header Cable (+) HR46 and Anode Loop Cab7e (t) LR46 in Anode Junction Box AJB (46-1) and AJB (46-2).

Using VOM, verify continuity (less than one ohm) across Anode Header Cable (+) HR46 and Anode Loop Cable (+) LR46 in Anode Junction Box AJB $(46-1)$ and $A J B(46-2)$.

8.2.4 (t) LR46 that were disconnected in Step 8.2.2.

NOTE: The steps shown in Paragraphs 8.3 and 8.4 may be done concurrently.

8.3 The following steps will verify pipe test conductors are (1) terminated on designated terminals in accordance with the Drawings and (2) labeled correctly with the pipe number or reference electrode. Record terminal number to which each conductor is connected.

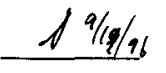

8.3.1

Test Station T(46-1)

4-inch SL-100-M9

w/6" ENC-M26a

Terminals 1 and 2

W320001.ATP. 614

$-11-$

(2) $4 / 23 / 97$

HNFWHE-SD-W320-ATR-001

Rev 0

$04 / 11 / 95$ 
, wh SN-200-M9

W/6" ENC-M26a

Reference Electrode

Test Station T(46-2)

4-inch SL-100-M9

W/6" ENC-M26a

4-inch $\mathrm{SN}-200-\mathrm{M9}$

W/6" ENC-M26a

$19 / 14 / 16$

8.3 .3

$19 / 10 / 96$

8.3 .4

$f^{9 / 1} / 26$

8.3.5

$$
\begin{aligned}
& \text { Delete } \\
& \text { ECN W } 320-110
\end{aligned}
$$$$
\text { 4-inch SL-100-M9 }
$$$$
\text { w/6" ENC-M26a }
$$$$
\text { 4-inch SN-200-M9 }
$$$$
\text { W/6" ENC-M26a }
$$$$
\text { 8-inch RW }
$$$$
\text { Reference Electrode }
$$$$
\text { Test Station T(46-5) }
$$$$
\text { 4-inch SL-100-M9 }
$$$$
\text { w/6" ENC-M26a }
$$$$
\text { 4-inch SN-200-M9 }
$$$$
W / 6^{*} \text { ENC-M26a }
$$$$
\begin{array}{ll}
\text { Terminals } & 3 \\
\text { Terminal } 5
\end{array}
$$

and 4

Terminals 1 and 2

Terminals 3 and 4

Terminals.

Terminal 5

Terminals 3 and 4

Terminals 1 and 2

Terminals 7 and 8

Terminal $S$

Terminals 1 and 2

Terminals 3 and 4

Terminals 7 and 8

Terminal 5

Terminals $\ldots$ and $z$

Terminals 3 and 4

Terminals

and

Terminal 5 


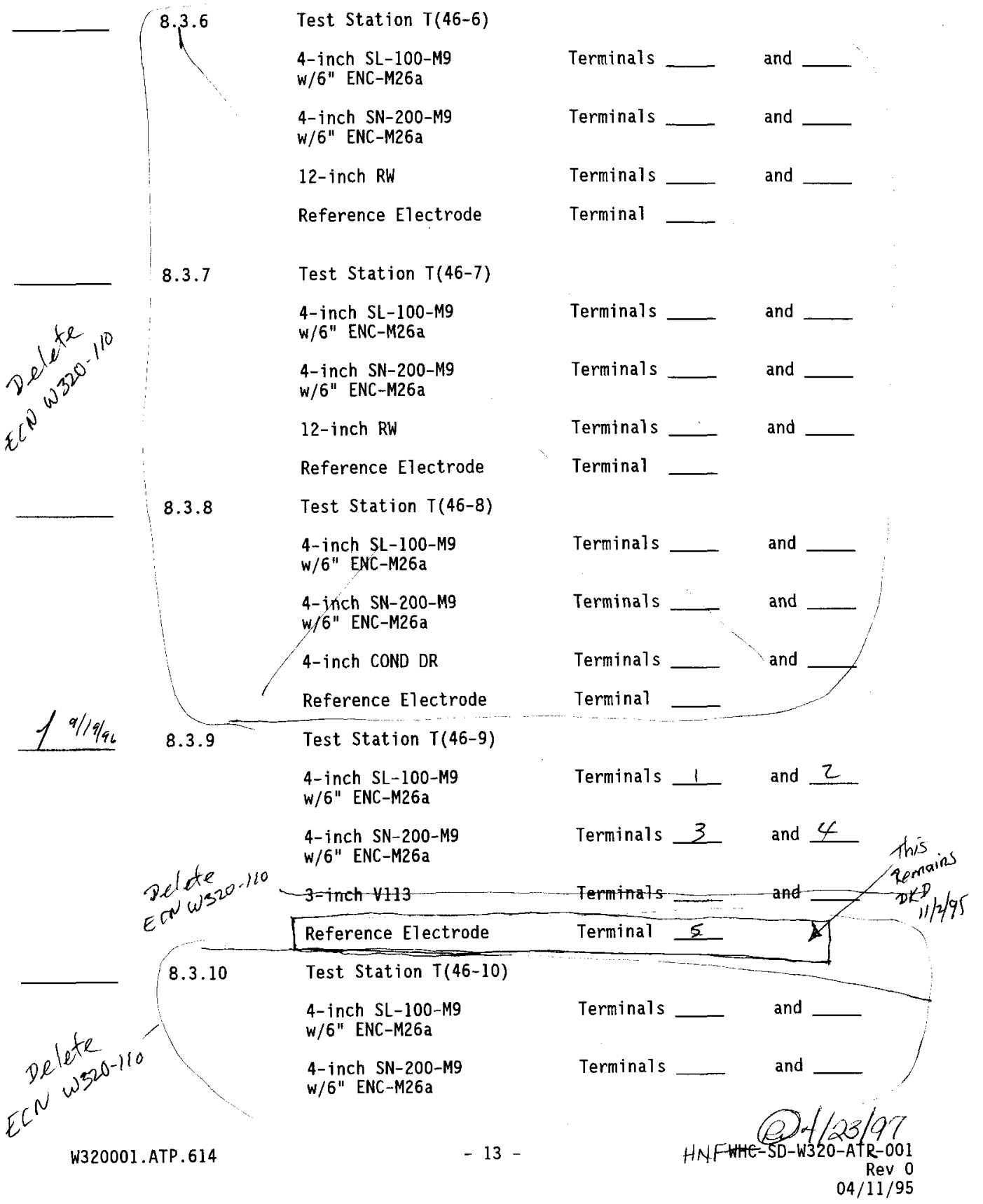




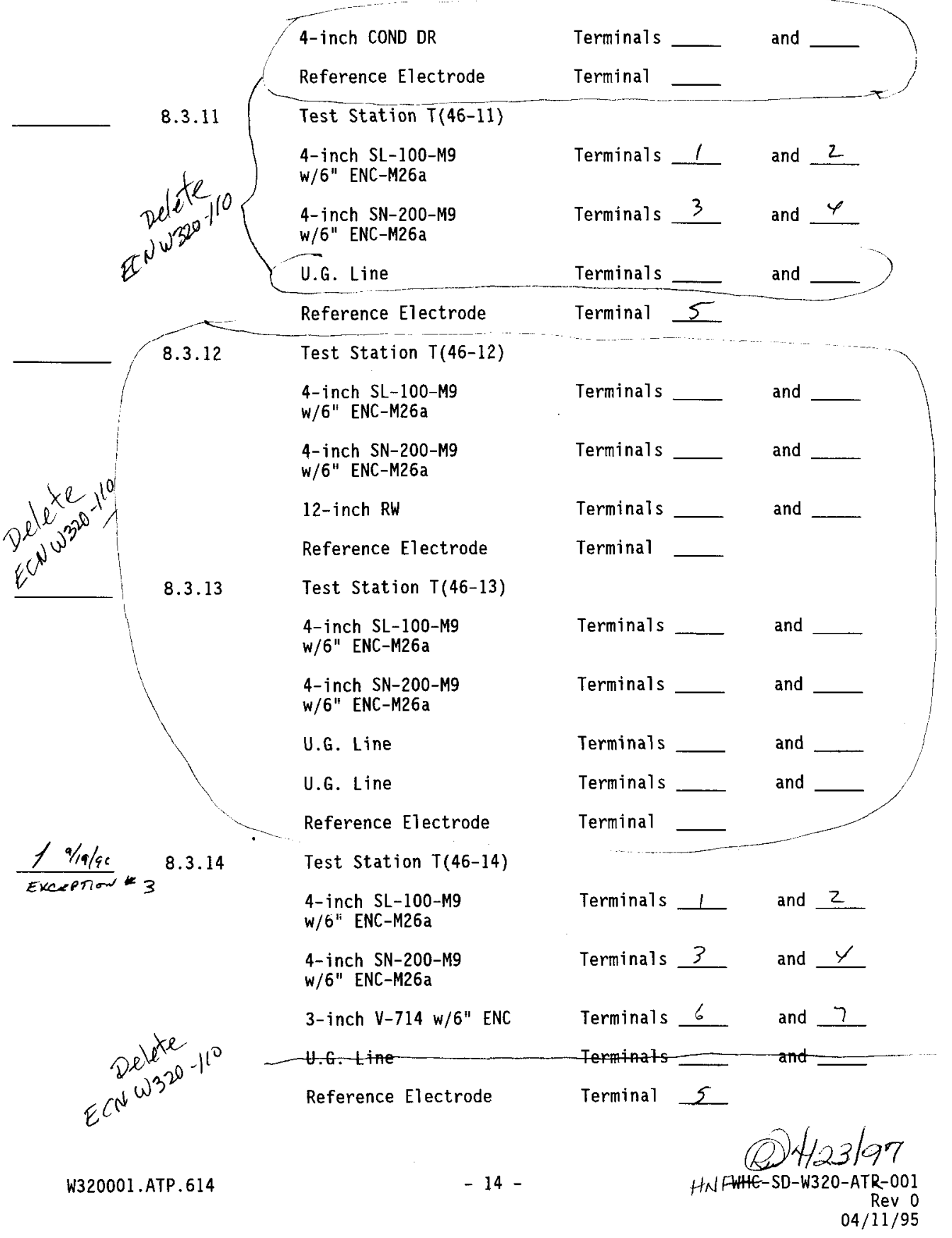




\subsubsection{Test Station T(46-15)}

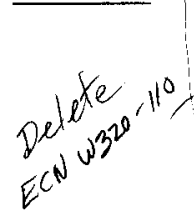
U.G. Line
U.G. Line
U.G. Line
Reference Electrode

Terminals

and

Terminals

Terminals

and

Terminal

8.4

Using a VOM, measure and record resistance between each set of pipe test conductors that are identified as being connected to the same pipe.

$19 / 1 \% / 96$ Resistance measured shall be less than $1 \mathrm{ohm}$.

8.4 .1

Record the following VOM data:

\begin{tabular}{l|l|l} 
Manufacturer & FLUKE & FLUKS \\
Model & $\frac{8024 B}{8060 A}$ \\
Serial Number mars & 0225 & $812-45-0 \gamma-011$ \\
\hline Calibration Sticker Data $4-30-97$ & $9-25-96$ \\
\hline
\end{tabular}

$119 / 96 \quad 8.4 .2$

Test Station T(46-1)

4-inch SL-100-M9 W/6" ENC-M26a

.10 ohms

4-inch SN-200-M9 w/6" ENC-M26a

11 ohms

$19 / 19 / 96$

8.4 .3

Test Station T(46-2)

4-inch SL-100-M9 w/6" ENC-M26a

.12 ohms

4-inch SN-200-M9 w/6" ENC-M26a

$\frac{.12}{2}$ ohms

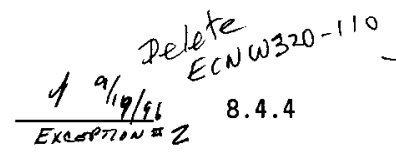

U.G. Line-

Test Station T(46-3)

4-inch SL-100-M9 w/6" ENC-M26a

.16 ohms

4-juch SN-200-M9 w/6" ENC-M26a

.15 ohms

$19 / 19 / 66 \quad 8.4 .5$

30-inch CMP

Test Station $T(46-4)$

$\eta \% / 26 / \frac{-0 \text { ond ohms }}{.3}$

4-inch SL-100-M9 w/6" ENC-M26a

.15 ohms

4-inch SN-200-M9 w/6" ENC-M26a

.16 ohms

8-inch RW

$1 \theta$ ohms

$\frac{y 2 / 96}{\text { excosons } 3}$

8.4.6 Test Station $T(46-5)$

4-inch SL-100-M9 w/6" ENC-M26a

W320001.ATP.614

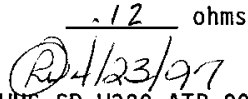

HNWE-SD-W320-ATR-001 


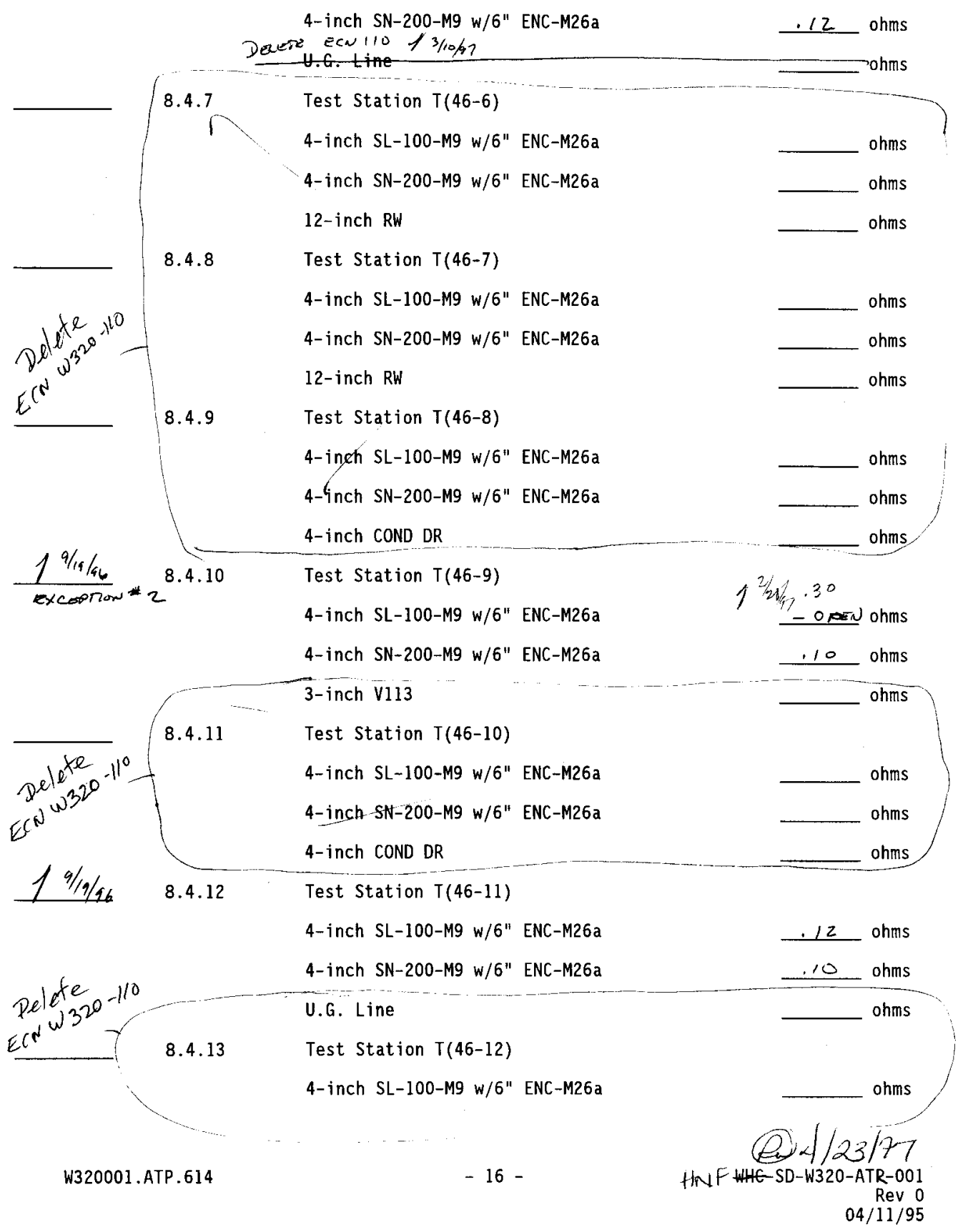


4-inch SN-200-M9 w/6" ENC-M26a

ohms

12-inch RW ohms

8.4.14 Test Station $T(46-13)$

4-inch SL-100-M9 w/6" ENC-M26a

ohms

4-inch SN-200-M9 w 6 6" ENC-M26a ohms

U.G. Line ohms

U.G. Line ohms

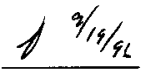

8.4.15

Test Station T(46-14)

Excoprow 3

4-inch SL-100-M9 w/6" ENC-M26a

4-inch SN-200-M9 w/6" ENC-M26a
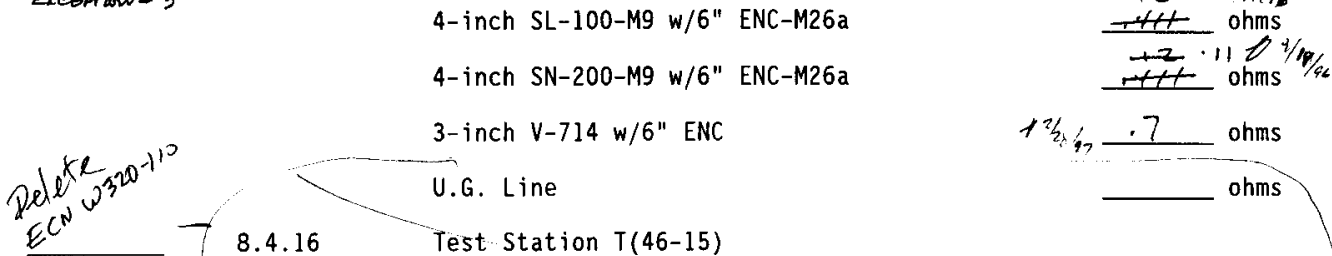

3-inch $V-714 w / 6 "$ ENC

U.G. Line

$12 / 26$

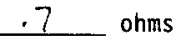

8.4 .16

Test Station T(46-15)

U.G. Line ohms

U.G. Line ohms

U.G. Line ohms

8.5

The following steps will provide the native potential of each new pipe using both the permanent reference electrode and a portable reference electrode for comparison.

NOTE: $\quad$ Connect the pipe test conductor to the positive terminal of

OFF Qस 4-10-97 $8.5 . a$ (SEB BELON)

EF $4-14-97$

$19 / 14 / 46$
8.5 .1 the Wave Form Analyzer and the lead from the permanent or portable reference electrode to the common terminal of the Wave Form Analyzer. Turn the mode switch, on the Wave Form Analyzer, to the DC position. (Place the portable reference electrode directly above the pipe for those tests that require the use of the portable reference electrode).

Test Station $T(46-1)$

Permanent Reference Electrode and 4-inch $S L-100-M 9$ w/6" ENC-M26a

Portable Reference Electrode and 4-inch SL-100-M9 w/6" ENC-M26a

Permanent Reference Electrode and 4-inch SN-200-M9 w/6" ENC-M26a

8.5.a OPIEN THE INPUT CIRCAIT BREAKER ON IEXISTINC AIECTIFIERS (ECN-624) II AND 14. WAIT A MINIMUM OF 96 HOUAS PRIOR TO PRRIZORMANOE OR NEXT STEP.

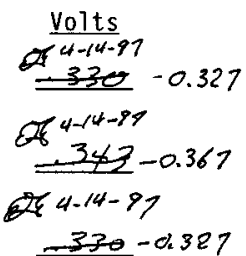

(fu) $4 / 23 / 97$ HNFWHE-SD-W320-ATR-001

Rev 0 


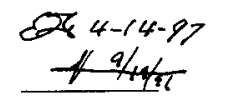

8.5 .2

684-14-97

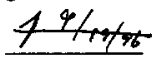

Q4.14-97

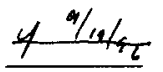

$874-14-97$

$79 / 19406$

8.5 .5

\section{5 .3}

8.5 .4
Portable Reference Electrode and 4-inch SN-200-M9 W/6" ENC-M26a

Test Station $T(46-2)$

Permanent Reference Electrode and 4-inch SL-100-M9 w/6" ENC-M26a

Portabie Reference Electrode and 4-inch SL-100-M9 w/6" ENC-M26a

Permanent Reference Electrode and 4-inch SN-200-M9 w/6" ENC-M26a

Portable Reference Electrode and 4-inch SN-200-M9 w/6" ENC-M26a

Test Station $\mathrm{T}(46-3)$

Permanent Reference Electrode and 4-inch SL-100-M9 w/6" ENC-M26a

Portable Reference Electrode and 4-inch SL-100-M9 w/6" ENC-M26a

Permanent Reference Electrode and 4-inch SN-200-M9 W/6" ENC-M26a

Portable Reference Electrode and 4-inch SN-200-M9 w/6" ENC-M26a

Test Station $T(46-4)$

Permanent Reference Electrode and 4-inch SL-100-M9 w/6" ENC-M26a

Portable Reference Electrode and 4-inch SL-100-M9 w/6" ENC-M26a

Permanent Reference Electrode and 4-inch SN-200-M9 w/6" ENC-M26a

Portable Reference Electrode and 4-inch SN-200-M9 w/6" ENC-M26a

Test Station T(46-5)

Permanent Reference Electrode and 4-inch SL-100-M9 w/6" ENC-M26a

Portable Reference Electrode and 4-inch SL-100-M9 w/6" ENC-M26a

Permanent Reference Electrode and 4-inch SN-200-M9 w/6" ENC-M26a
\&8 4-14-97

$-3+3-0.366$

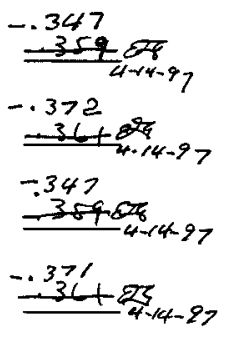

$-.312$

$-555{ }_{4}^{278}$

$-.394$

$+60 \times 48-97$

$-.3 / 2$

$=3+008-14-97$

$-.393$

$-36687-4-97$

$-.318$
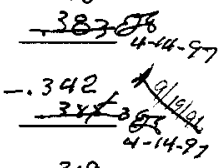

$-.318$

$\frac{38-8 \times 8}{4-14-97}$

$-.342$

$-38348$ $4-14-87$

$-.334$

$\frac{.36587}{4-14-97}$

$-.357$

-3658

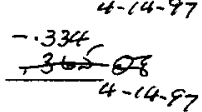




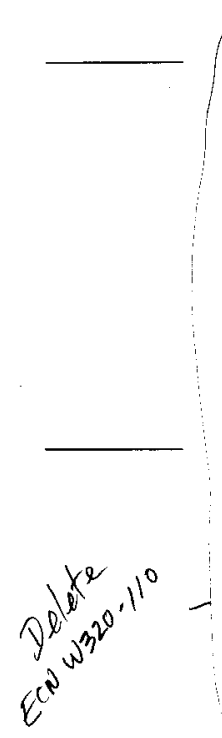

Portable Reference Electrode and 4-inch

SN-200-M9 w/6" ENC-M26a

8.5.6 Test Station $T(46-6)$

Permanent Reference Electrode and 4-inch SL-100-M9 w/6" ENC-M26a

Portable Reference Electrode and 4-inch SL-100-M9 w/6" ENC-M26a

Permanent Reference Electrode and 4-inch SN-200-M9 w/6" ENC-M26a

Portable Reference Electrode and 4-inch SN-200-M9 W/6" ENC-M26a

\subsubsection{Test Station $\mathrm{T}(46-7)$}

Permanent Reference Electrode and 4-inch SL-100-M9 w/6" ENC-M26a

Portable Reference, Electrode and 4-inch SL-100-M9 W/6" ENC-M26a

Permanent Reference Electrode and 4-inch SN-200-M9 w/6" ENC-M26a

Portable Reference Electrode and 4-inch SN-200-M9 W/6" ENC-M26a

\subsubsection{Test Station $\mathrm{T}(46-8)$}

Permapent Reference Electrode and 4-inch SL-100-M9 w/6" ENC-M26a

Portable Reference Electrode and 4-inch SL-100-M9 w/6" ENC-M26a

Permanent Reference Electrode and 4-inch $\mathrm{SN}-200-\mathrm{Mg} \mathrm{W} / 6$ " ENC-M26a

Portable Reference Electrode and 4-inch SN-200-M9 w/6" ENC-M26a

Test Station T(46-9)

Permanent Reference Electrode and 4-inch SL-100-M9 w/6" ENC-M26a

Portable Reference Electrode and 4-inch SL-100-M9 w/6" ENC-M26a

Permanent Reference Electrode and 4-inch SN-200-M9 W/6" ENC-M26a

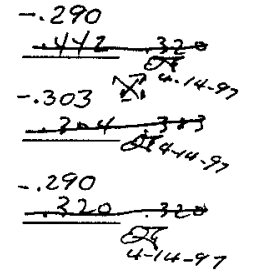


Portable Reference Electrode and 4-inch

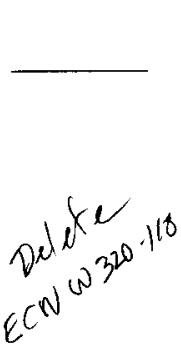

2) $4-14-97$

$+\frac{1115 / 4}{4}$
8.5 .10

8.5 .11

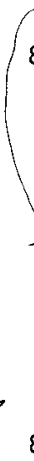

\section{SN-200-M9 w/6" ENC-M26a}

Test Station T(46-10)

Permanent Reference Electrode and 4-inch SL-100-M9 w/6" ENC-M26a

Portable Reference Electrode and 4-inch SL-100-M9 w/6" ENC-M26a

Permanent Reference Electrode and 4-inch SN-200-M9 w/6" ENC-M26a

Portable Reference Electrode and 4-inch $\mathrm{SN}-200-\mathrm{M} 9 \mathrm{w} / 6 "$ ENC-M26a

Test Station $T(46-11)$

Permanent Reference Electrode and 4-inch SL-100-M9 w/6" ENC-M26a

Portable Reference Electrode and 4-inch SL-100-M9 W/6" ENC-M26a

Permanent Reference Electrode and 4-inch SN-200-M9 w/6" ENC-M26a

Portable Reference Electrode and 4-inch $\mathrm{SN}-200-M 9 \mathrm{w} / 6^{\prime \prime}$ ENC-M26a

\section{5 .12}

隹<smiles>[X]C1CCCCC1</smiles>
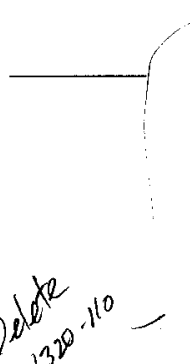

Test Station T(46-12)

Permanent Reference Electrode and 4-inch $\mathrm{SL}-100-M 9$ w/6" ENC-M26a

Portable Reference Electrode and 4-inch SL-100-M9 w/6" ENC-M26a

Permanent Reference Electrode and 4-inch SN-200-M9 w/6" ENC-M26a

Portable Reference Electrode and 4-inch SN-200-M9 w/6" ENC-M26a

8.5.13 Test Station T(46-13)

Permanent Reference Electrode and 4-inch SL-100-M9 w/6" ENC-M26a

Portable Reference Electrode and 4-inch SL-100-M9 w/6" ENC-M26a

Permanent Reference Electrode and 4-inch SN-200-M9 w/6" ENC-M26a

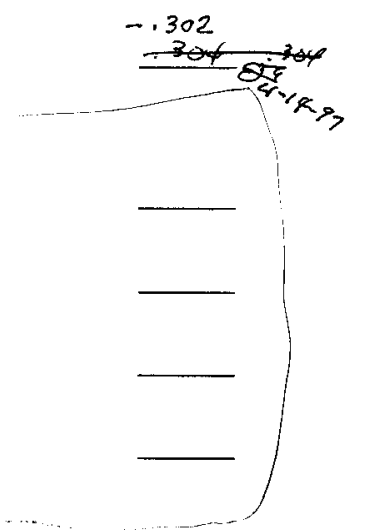

$-.357$

$\pm 4+185$
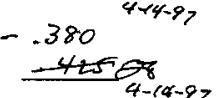

$-.357$

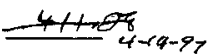

$-.380$

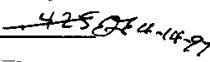




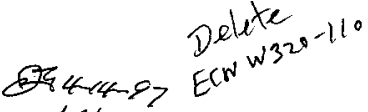

$x^{4 / 2 y+26}$

8.5 .14
Rortable Reference Electrode and 4-inch SN-200-M9 W/6" ENC-M26a

Test Station $T(46-14)$

Permanent Reference Electrode and 4-inch SL-100-M9 w/6" ENC-M26a

Portable Reference Electrode and 4-inch SL-100-M9 w/6" ENC-M26a

Permanent Reference Electrode and 4-inch SN-200-M9 w/6" ENC-M26a

Portable Reference Electrode and 4-inch $\mathrm{SN}-200-\mathrm{M9} \mathrm{w} / 6^{\prime \prime}$ ENC-M26a

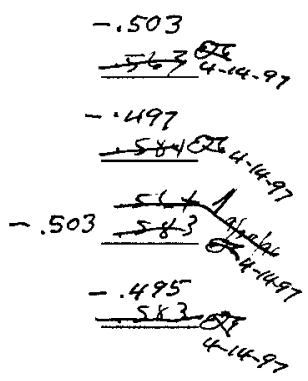

8.6

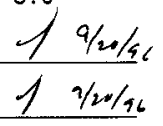

$19 / 20 / 96$

$1^{9 / 20 / 96}$
The following

8.6 .1

8.6.2

8.6 .3

8.6 .4

Verify Rectifier 46 input circuit breaker is OPEN.

Verify all COARSE and FINE output transformer taps on rectifier are set at the lowest levels (Coarse - A and Fine - 1).

Close circuit breaker in Distribution Panelboard, Control/Lunch Trailer.

Close rectifier input circuit breaker and disconnect switch at rectifier. Using meter on rectifier, record volts and amperes, and then open input circuit breaker. Set fine tap to next higher setting and leave coarse tap as previously set. Close input circuit breaker again and record volts and amperes, then open the input circuit breaker. Continue adjusting the output of the rectifier in steps until either the dc volts or dc amperes (whichever is first) approaches, but does not exceed, the nameplate rating of rectifier.

\section{Transformer Taps \\ Coarse Fine}

A

A

A

A

A

B

B

B

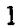

2

3

4

5

1

2

3

W320001.ATP.614

$\frac{d c \text { Output }}{\text { Volts Amp }}$

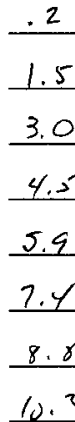

10.3

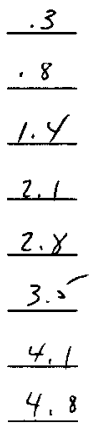

(2) $4 / 123 / 97$

HWNFHE-SD-W320-ATR-001 
$1 / 9 / 20 / 96$

8.7

$19 / 20 / 96$

$19 / 20 / 94$

$19 / 20 / 95$

$19 / 20 / 96 \quad 8.7 .4$

$19 / 20 / 96 \quad 8.7 .5$

$19 / 20 / 96 \quad 8.7 .6$

$19 / 20 / 96 \quad 8.7 .7$

8.8

$12 / 20 / 96$

8.6.5

8.7 .2

8.8 .1
The following steps will verify that if either the Anode Header Cable or the Anode Loop Cable is severed, the cathodic protection system will cont inue to function properly.

8.7.1 Close rectifier input circuit breaker and record the current shown on the rectifier ammeter. 10.9 amperes.

Open rectifier input circuit breaker.

Disconnect Anode Header Cable ( + ) HR46 from positive terminal of rectifier, leaving Anode Loop Cable ( + ) LR46 connected.

close rectifier input circuit breaker and record the current shown on the rectifier ammeter. 4. $C$ amperes.

Open rectifier input circuit breaker and disconnect Anode Loop Cabie (t) LR46 and reconnect Anode Header Cable (t) HR46.

close rectifier input circuit breaker and record the current shown on the rectifier ammeter. 7,1 amperes.

Open rectifier input circuit breaker and reconnect Anode Loop Cable (+) LR46.

The following steps will verify proper operation of the ground bed system.

Verify the Mode switch, on the Wave Form Analyzer, is in the OFF position. 


\section{$19 / 20 / 28 \quad 8.8 .2$}

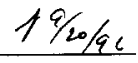

8.8 .3

$19 / 20 / 26$

8.8 .4

$12 / 20 / 2$

$19 / 2 / 96$

8.8 .6

8.8 .5
Connect positive terminal of the Wave Form Analyzer to a protected pipeline test conductor through a portable test reel at various convenient test stations for the following procedure.

Connect common terminal of the Wave Form Analyzer to a portable copper-copper sulfate reference electrode.

Turn the Mode switch, on the Wave Form Analyzer, from the OFF position to the DC position.

Record the following portable reference electrode data:

Manufacturer

Mode 1 and type

Close rectifier input circuit breaker, place the portable reference electrode over each anode location and measure pipe to soil potential using the Wave Form Analyzer. Record pipe to soil potential at each anode location. Values should be more negative than $(-) 0.85 \mathrm{~V}$ dc (ie, $(-) 0.86 \mathrm{~V} \mathrm{dc}$ ).

NOTE: A pipe locator may be used to locate anodes if necessary.

$19 / 20 / a$

8.8 .7

\begin{tabular}{|c|c|c|c|c|}
\hline \multirow{2}{*}{\multicolumn{2}{|c|}{$\frac{\text { Anode }}{A(46-1)}$}} & Volts & Anode & Volts \\
\hline & & -9.67 & $A(46-24)$ & $-8.9 /$ \\
\hline & $A(46-2)$ & $-7,21$ & $A(46-25)$ & $-7,00$ \\
\hline & $A(46-3)$ & -7.15 & $A(46-26)$ & -5.82 \\
\hline & $A(46-4)$ & -8.15 & $A(46-27)$ & -7.75 \\
\hline & $A(46-5)$ & -7.45 & $A(46-28)$ & -6.42 \\
\hline & $A(46-6)$ & -8.36 & $A(46-29)$ & -4.72 \\
\hline & $A(46-7)$ & -6.80 & $A(46-30)$ & $-7.6 y$ \\
\hline & $A(46-8)$ & -7.250 & $A(46-31)$ & $-7.4 y$ \\
\hline & $A(46-9)$ & -6.99 & $A(46-32)$ & $-7,50$ \\
\hline & $A(46-10)$ & -4.69 & $A(46-33)$ & -5.14 \\
\hline & $A(46-11)$ & -4.48 & $A(46-34)$ & -6.78 \\
\hline & $A(46-12)$ & -4.86 & $A(46-35)$ & $=8.57$ \\
\hline & $A(46-13)$ & -3.66 & $A(46-36)$ & -7.73 \\
\hline & $A(46-14)$ & $=3.30$ & $A(46-37)$ & .4 .72 \\
\hline 7 'sourt & $A(46-15)$ & -6.12 & $A(46-38)$ & $=9.10$ \\
\hline $\begin{array}{l}\text { of suristis } \\
\text { poings }\end{array}$ & $A(46-16)$ & -11.28 & $A(46-39)$ & $-9,18$ \\
\hline
\end{tabular}

(2) 4123177

HNFWHE=SD-W320-ATR-001 


\begin{tabular}{|c|c|c|c|}
\hline Anode & Volts & Anode & Volts \\
\hline$A(46-17)$ & -10.68 & $A(46-40)$ & -8.03 \\
\hline$A(46-18)$ & -9.58 & $A(46-41)$ & $=6.17$ \\
\hline$A(46-19)$ & -6.78 & $A(46-42)$ & -6.80 \\
\hline$A(46-20)$ & -5.69 & $A(46-43)$ & -6.67 \\
\hline$A(46-21)$ & -5.17 & $A(46-44)$ & -4.38 \\
\hline$A(46-22)$ & -5.78 & $A(46-45)$ & -6.84 \\
\hline$A(46-23)$ & $=7.54$ & $A(46-46)$ & -5.56 \\
\hline
\end{tabular}

$19 / 25 / 56$

$19 / 20 / 86$

8.9
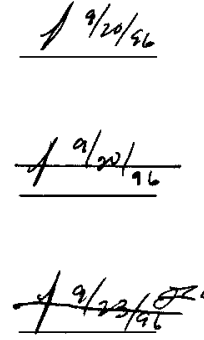

8.9 .3

25 4-15-97

$\frac{\text { Eर 4-15-97 }}{\text { exespon } 4}$
8.8.8

8.8 .9
8.9.1 8.9.4
Turn the Mode switch, on the Wave Form Analyzer, to the OFF position and disconnect leads.

Open the disconnect switch at the rectifier.

The following steps will verify proper operation of the cathodic protection system:

Position the ten position DIP switch on the Pulse Generator (located in the rectifier control panel) as follows: SWl, 2, and 3 in the OFF position and SW4, 5, 6, 7, 8, 9, and 10 in the ON position.

8.9.2. DELETE

Open the input circuit breaker on existing-Rectifior 11 , focated-approximately-50-feet south of Building 241-AN-271 and in Rectifier 14, located outside the "A" Fank-Farm fenee near the northwest-cornet.

Close Rectifier 46 input circuit breaker and the disconnect switch at the rectifier and verify the rectifier has been

8.9.3a ECN24 SESPACIZ $24-4$ energized for 24 hours prior to the following test.

Measure and record the ON and OFF pipe-to-soil potential of each protected pipe by use of the Waveform Analyzer. * For ouzuzre protected pipe- the Off values should be oqual to or more. EC-N-298 negative than $(-) 0.85 \mathrm{~V}$ de or the ON values shoutd be- $100 \mathrm{mV}$ more-negative than the Off values. If these values are not attainable by use of the existing permanent reference electrode a portable reference electrode may be used. For unprotected pipe, there is no criteria and the values will be recorded for record purposes. The unprotected pipes are designated below by an asterisk.

NOTE: Connect positive terminal of the Waveform Analyzer to the reference electrode terminal and the common terminal on the Waveform Analyzer to the pipe test conductor terminal. Turn the Mode switch from the OFF 8.9.4 position to the WFA position, record values, then turn * ADO RCN-299 to the OFF position. *SEE RAGE 24A ECN-624 For protected pipe the OFF value should be equal to or *aator than $(-) 0.85 \mathrm{Vdc}$ or the OFF value should be $100 \mathrm{fm}$ more negative than the native potential as/previously recorded. 
94 4-15-97 8.9.3a Verify proper operation of the pulse generator by connecting a VOM ECN- 624 across the $\mathrm{OC}$ shunt on the output of the rectifier and observe a SEIE PACB 24 sudden variation in current corresponding to cycle of rectifier pulse SELE PAC 24 generator (approximately every four seconds).

ECN-624 NOTE: SEE PAGE 24

Voltage readings obtained during this test are displayed on the WFA as positive values, and should be interpreted and recorded as negative values. 
$\frac{284-15-97}{2 x \cos 100}$

Ef $4-15.97$

Exeation tu

$Q_{4-15-97 \text { pelete }}^{7} 3320-110$ $\frac{7 \text { ECN }}{\text { Excopion }} \times 4.9 .4 .3$

$6 \sqrt{6} 4-15-97$

$\frac{f^{2 / 25}}{\text { excotion } 4}$

8.9.4.4

28 $4-15-97$

8.9 .4 .5

Exention 4

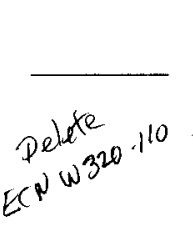

Test Station T(46-1)

Reference Electrode and 4-inch

SL-100-M9 w/6" ENC-M26a

Reference Electrode and 4-inch

SN-200-M9 w/6" ENC-M26a

Test Station T(46-2)

Reference Electrode and 4-inch

SL-100-M9 w/6" ENC-M26a

Reference Electrode and 4-inch

$\mathrm{SN}-200-\mathrm{M} 9 \mathrm{w} / 6^{\prime \prime}$ ENC-M26a
$-3.777-1.144$

Volts or 4-15-97

$0 N+5 \times 4 \times 0 E F+584$

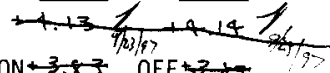

$\mathrm{ON}+\frac{3.83}{3.800} \mathrm{OFF}+\frac{3.5}{1.10}$

$-3.500-1.110$

8) $4-15-97$

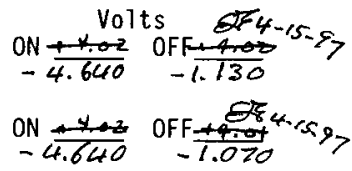

Referonce Electrode and U.G. tine *- - OA

OFF

Test Station T(46-3)

Reference Electrode and 4-inch

SL-100-M9 w/6" ENC-M26a

Reference Electrode and 4-inch

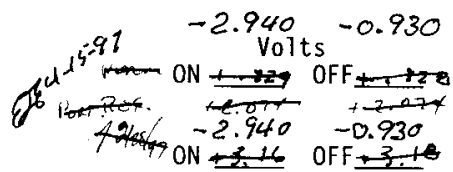

SN-200-M9 w/6" ENC-M26a

Reference Electrode and 30-inch

Test Station T(46-4)

Reference Electrode and 4-inch

SL-100-M9 w/6" ENC-M26a

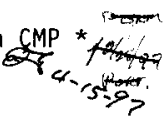

Reference Electrode and 4-inch

$\mathrm{SN}-200-\mathrm{M} 9 \mathrm{w} / 6^{\prime \prime}$ ENC-M26a

Reference Electrode and 8-inch RW *

Test Station T(46-5)

Reference Electrode and 4-inch

SL-100-M9 w/6" ENC-M26a

$-0.960-0.650$

$\mathrm{ON}^{+2} \mathrm{OFF}+20$

Reference Electrode and 4-inch

SN-200-M9 w/6" ENC-M26a

Reference Electrode and U.G. Line *

8.9.4.6 Test Station $T(46-6)$

Reference Electrode and 4-inch

SL-100-M9 w/6" ENC-M26a

Volts ofersis.

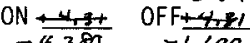

$-4.380-1.100$

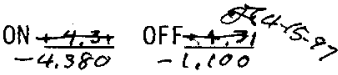

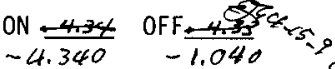

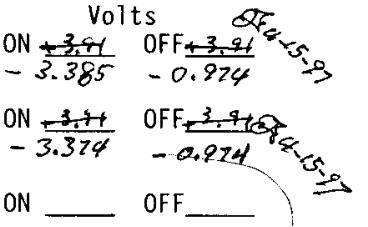

Reference Electrode and 4-inch

$\mathrm{SN}-200-\mathrm{Mg} \mathrm{w} / 6^{\prime \prime}$ ENC-M26a

Reference Electrode and 12-inch RW *

$\mathrm{ON} \longrightarrow \mathrm{OFF}$

Volts

ON

OFF

ON

OFF

(2) $4 / 23 / 97$

W320001.ATP. 614

$-25-$

HNFWHE-SD-W320-ATR-00I 
Reference Electrode and 4-inch

$\mathrm{SN}-200-\mathrm{Mg} \mathrm{W} / 6^{\prime \prime} \mathrm{ENC}-\mathrm{M} 26 \mathrm{a}$

Reference Electrode and 12-inch RW *

8.9.4.13 Test Station T(46-13)

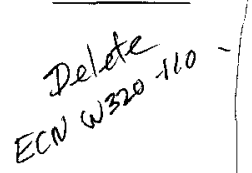

Reference Electrode and 4-inch

SL-100-M9 w/6" ENC-M26a

Reference Electrode and 4-inch

SN-200-M9 w/6" ENC-M26a

Reference Electrode and U.G. Line *

Reference Electrode and U.G. Line *

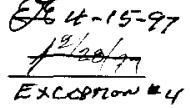

8.9.4.14

Test Station T(46-14)

8.9.4.15 Test Station T(46-15)

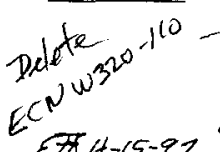

.

\section{ECN-624}

8.9.4.15a

SEE BREOW

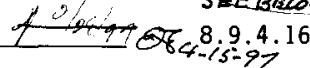

$42 / 2,70-15-97$

8.9 .4 .17

$41,040-16-97$

8.9 .4 .18

1:204-16-97

8.9 .5

END OF TEST

$44-15 \rightarrow 78.9 .4 .15 a$

EN-6.24

W320001.ATP.614
$-27-$
Reference Electrode and 4-inch

SL-100-M9 w/6" ENC-M26a

Reference Electrode and 4-inch

SN-200-M9 w/6" ENC-M26a

Reference Electrode and 3-inch V-714 w/6" ENC *

Reference Electrode and U.G. Line *

ON

OFF

ON

OFF

Volts

ON

ON

$-\quad 0 F F$

ON OFF

ON

OFF

Volts

ON 2.20

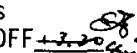

$-3.201 \quad-1.098 \times 5$

ON 3,2

$-3.19$

$\mathrm{ON}^{+}+4.2 \mathrm{x}$

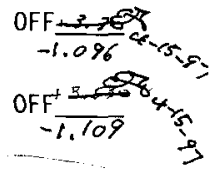

ON

OFF.

Reference ETectrode and U.G. Line *

Volts

Reference Electrode and U.G. Line *

Reference Electrode and U.G. Line *

Turn the Mode switch, on the Wave Form Analyzer, to the OFF position and disconnect leads.

Open disconnect switch at the rectifier.

Close the input circuit breaker on existing Rectifiers 11 and 14 that were opened in previous step.

Testing complete, secure from test.
Verify continued proper operation of the pulse generator by connecting a VOH across the DC shunt on the output of the rectifier and observe a sudden variation in current corresponding to cycle of rectifier pulse generator (approximately every four seconds).
$S_{4}+1 / 23 / 77$

HNF WIE-SD-W320-ATR-001 


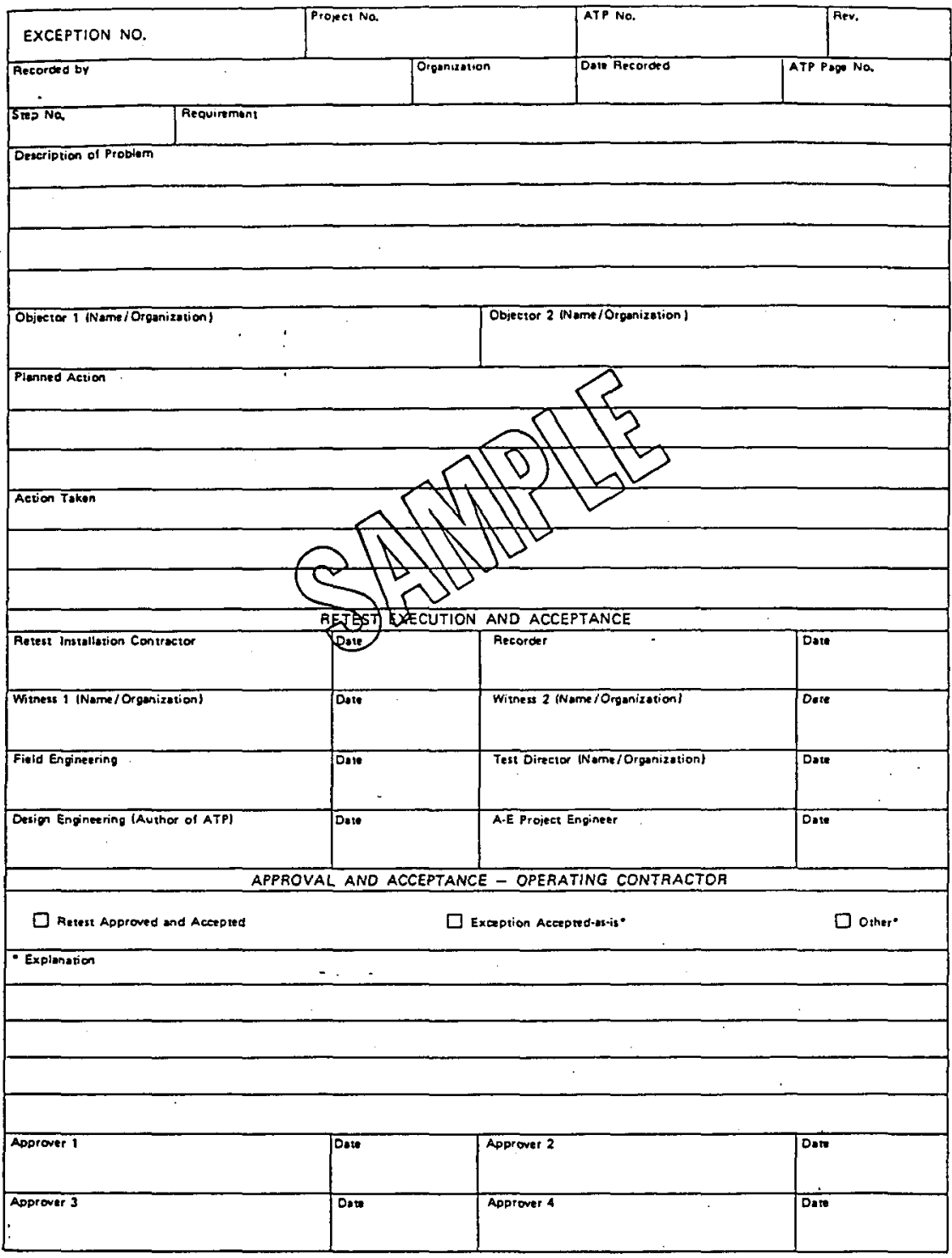

KEN-428 (6.85) 


\section{ATP No. WHC-SDD-W-320-ATP-001}

Appendix A

\section{Exceptions}




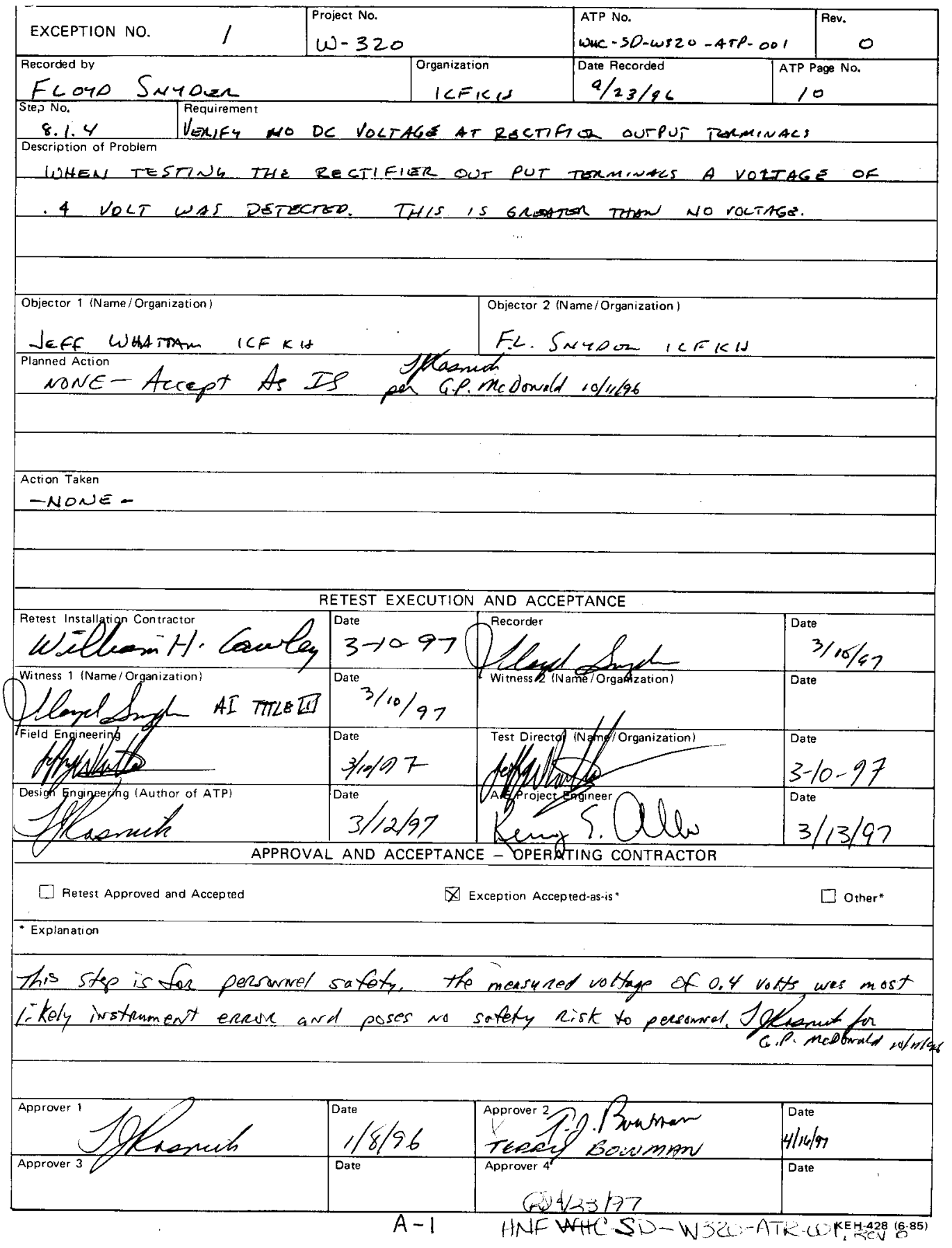




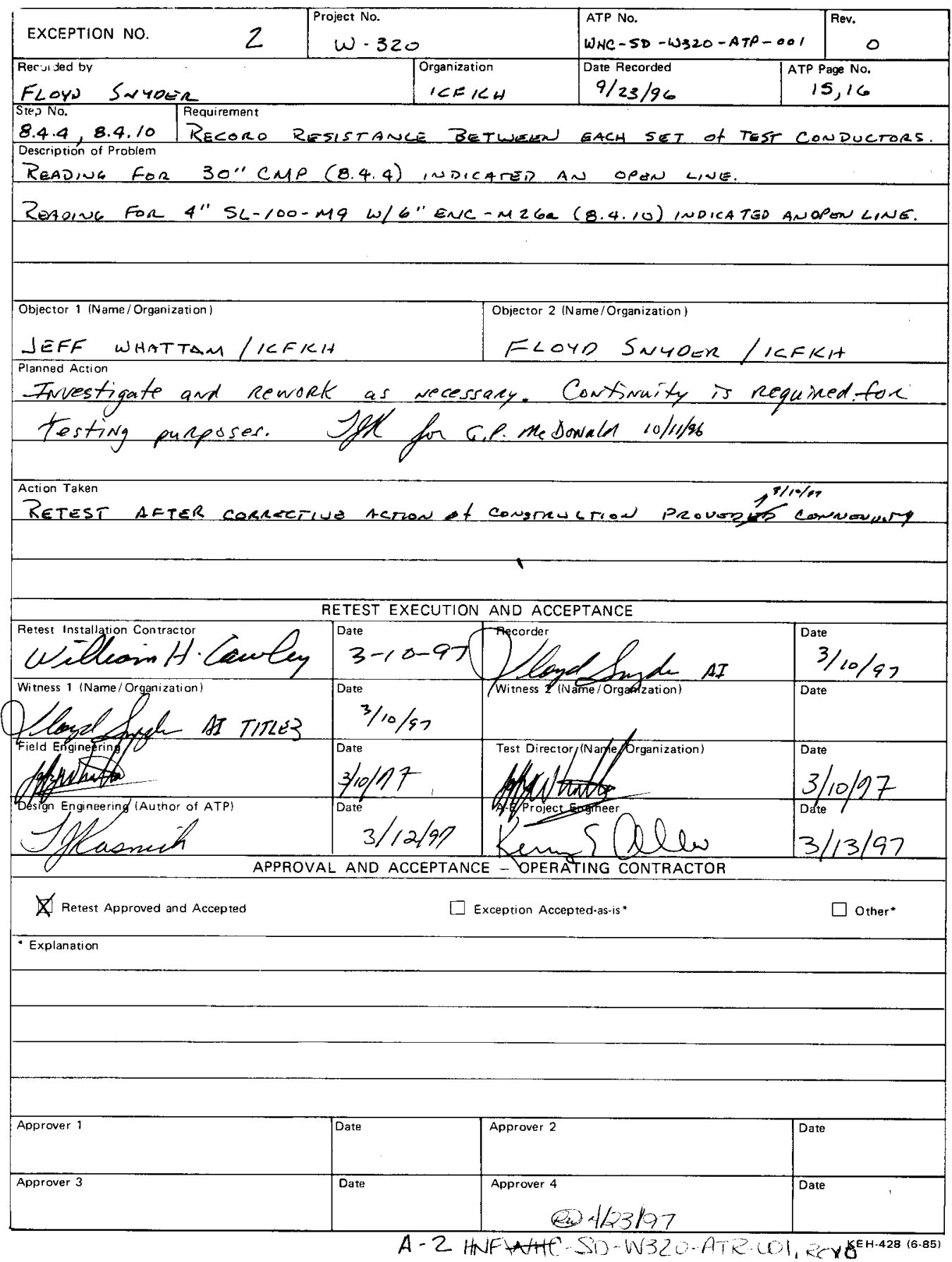


The following retesting was accomplished on $2 \phi / 28 / 97$ to resolve the exception on ATP-001.

Exception 2: Planed action is repair and retest.

The $30^{\prime \prime}$ CMP leads were reexcavated repairs made to the leads and rebackfilled.

Retesting was accomplished with the following results:

Page 158.4 .430 -inch CMP $\frac{3}{3}$ onms

Page 16 8.4.10 4-inch SL-100-M9 w/6" ENC-M25a .30 ohms

Exception 3: Planed action is to complete the installation of the 3" V-714 w/6" Enc. The UG line was deleted in other parts of the ATP and was missed on page 16 by ECN 110 , ECN needed to complete.

$V-714$ was installed into test station 46-14.

Tests of the V-714 in test station had the following results: Page 14 8.3.14 3" V-714 w/6" Enc Terminals 6 and 7 page $178.4 .153^{\prime \prime} \mathrm{V}-714 \mathrm{w} / 6^{\prime \prime}$ Enc $\frac{.7}{\text { ohms }}$

Exception 4: Planed action is to complete the installation of 3 " V-714, Repair the 30" CMP and ECN needed to for 3" VI13 deleted per ECN 110.

The 30" CMP was repaired and the 3" V-714 line was installed in test station 46-14, will need to have wire markers installed and permanent labels installed at terminals (Punch list).

Page 24 8.9.4 requires the Wave Form Analyzer to be connected with the Positive terminal of the Analyzer to the reference electrode terminal and the common terminal to the pipe test conductor terminal. This connection will cause positive results, by reversing they would be negative. The results should be considered negative when considering acceptance.

Test of the items were as follows:

Page 25 8.9.4.3 Test Station $\mathrm{T}(46-3)$ Reference Electrode and 30-inch CMP portable Electrode and 30 -inch CMP

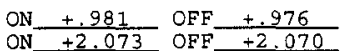

Reference Electrode and SL-100-M9 Reference Electrode and SL-100-M9

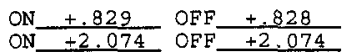

Page 27 8.9.4.14 Test Station $T(46-14)$ Reference Electrode and 3 " V-714

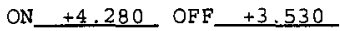

Page 26 8.9.4.9 Test Station $T(46-9)$ V113 has been deleted per ECN 110 need $E C N$ for this test.

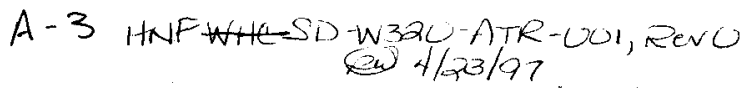




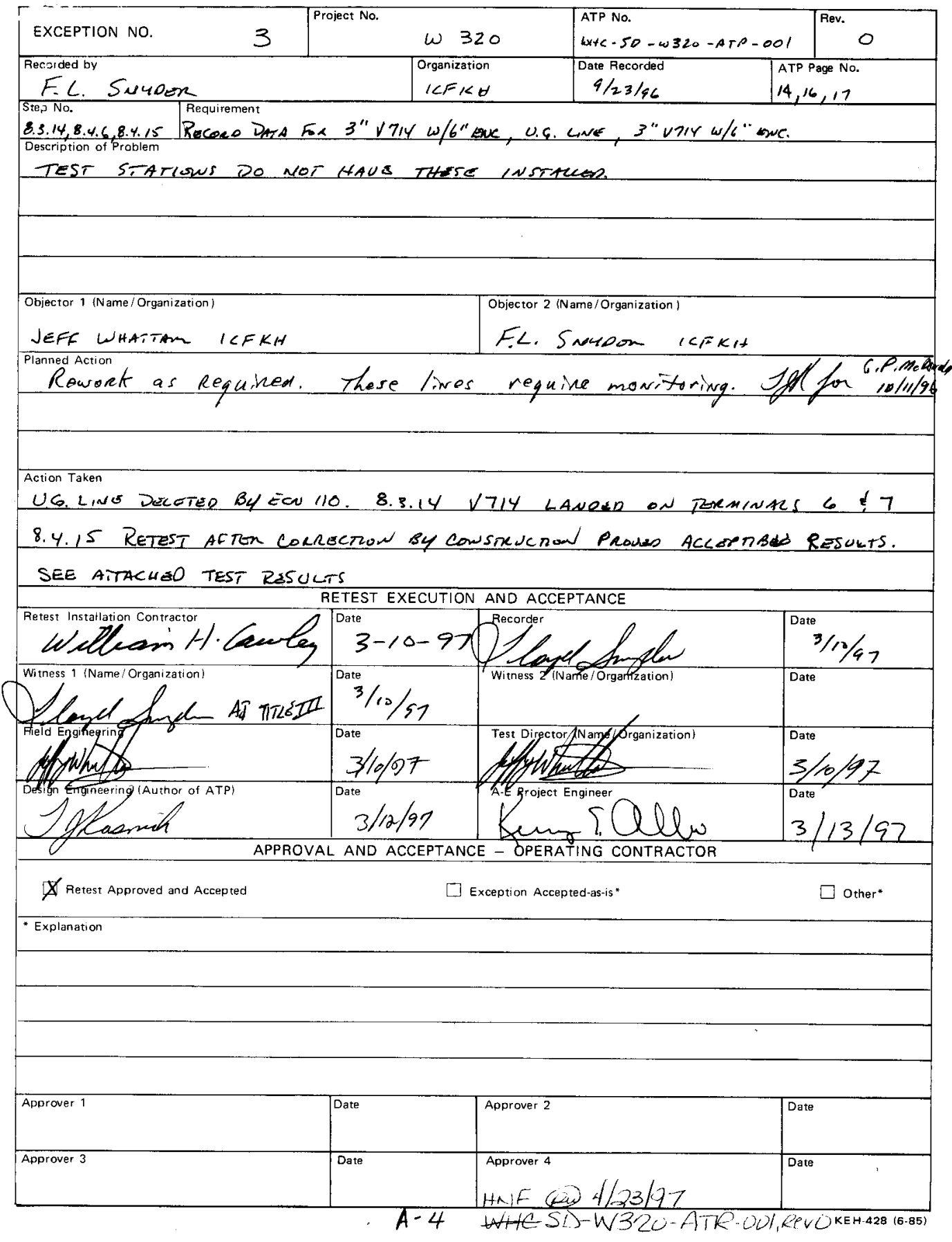




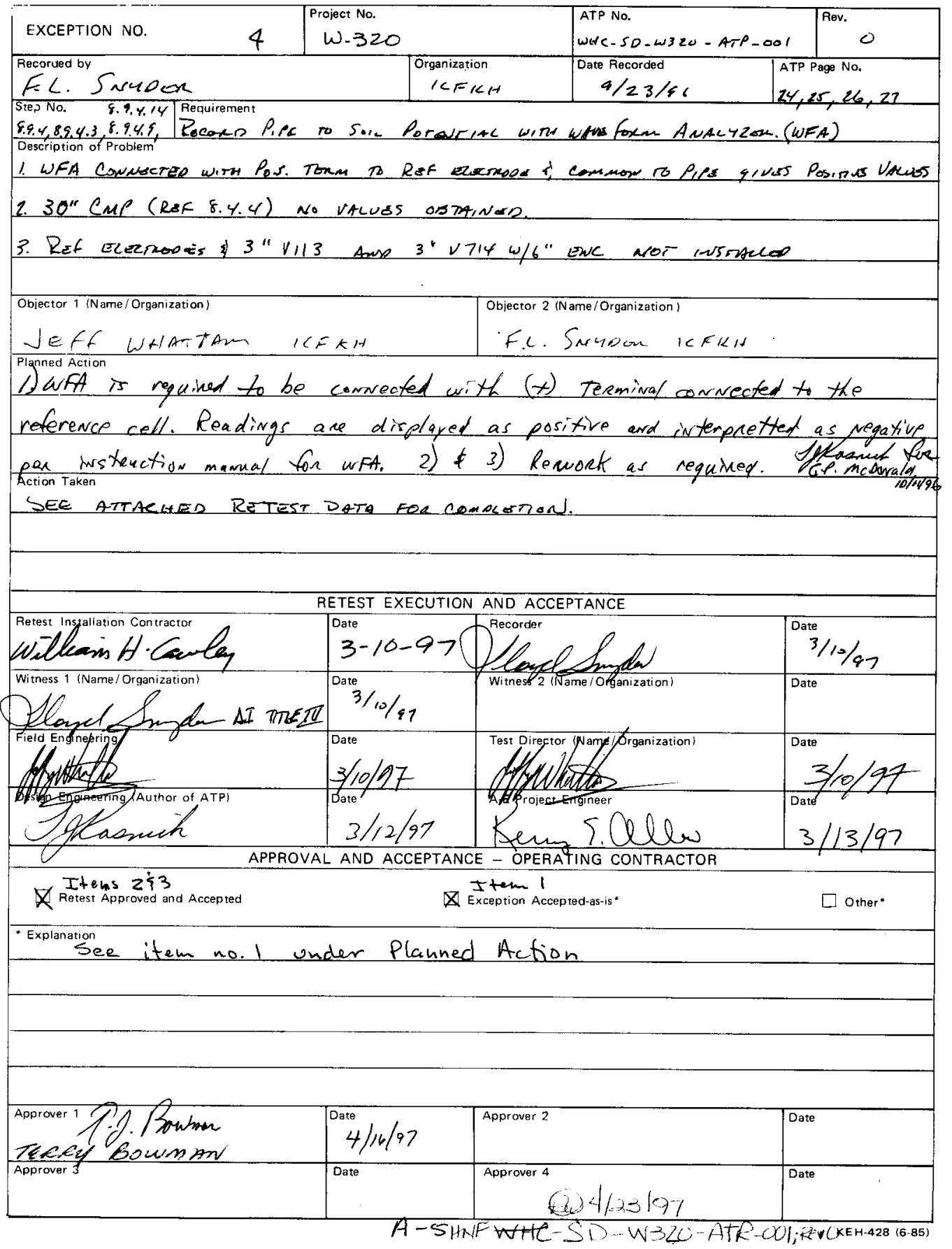


The following retesting was accomplished on $2 \beta / 28 / 97$ to resolve the exception on ATP-001.

Exception 2: Planed action is repair and retest.

The 30" CMP leads were reexcavated repairs made to the leads and rebackfilled.

Retesting was accomplished with the following results:

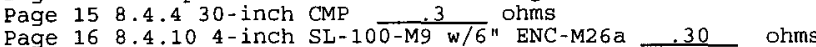

Exception 3: Planed action is to complete the installation of the 3" V-714 w/6" Enc. The UG line was deleted in other parts of the ATP and was missed on page 16 by ECN 110, ECN needed to complete.

V-714 was installed into test station 46-14.

Tests of the V-714 in test station had the following results: Page 14 8.3.14 $3^{n}$ V-714 w/6" Enc Terminals 6 and 7 Page 17 8.4.15 3" V-714 w/6" Enc $\frac{.7}{\text { ohms }}$

Exception 4: Planed action is to complete the installation of 3 " V-714, Repair the 30" CMP and ECN needed to for 3" V113 deleted per ECN 110.

The 30" CMP was repaired and the $3 " \mathrm{~V}-714$ line was installed in test station 46-14, will need to have wire markers installed and permanent labels installed at terminals (Punch list).

Page 24 8.9.4 requires the Wave Form Analyzer to be connected with the Positive terminal of the Analyzer to the reference electrode terminal and the common terminal to the pipe test conductor terminal. This connection will cause positive results, by reversing they would be negative. The results should be considered negative when considering acceptance.

Test of the items were as follows:

Page 25 8.9.4.3 Test Station $\mathrm{T}(46-3)$ Reference Electrode and 30 -inch CMP Portable Electrode and 30-inch CMP

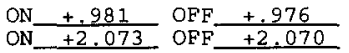

Reference Electrode and SL-100-M9

Reference Electrode and SL-100-M9

$\mathrm{ON}+\frac{+.829}{+2.074} \mathrm{OFF}+\frac{+.828}{+2.074}$

Page 27 8.9.4.14 Test Station $\mathrm{T}(46-14)$ Reference Electrode and 3 " $\mathrm{V}-714$

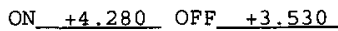

Page 26 8.9.4.9 Test Station $\mathrm{T}(46-9)$

V113 has been deleted per ECN 110 need ECN for this test.

$$
\begin{aligned}
& \text { A-6 HWIF } 4 / 23 / 97 \\
& \text { WIC-SD-W320-ATR-o01, Revo }
\end{aligned}
$$

